\title{
Die dodekapropheton: Twaalf klein profete of een geheel?
}

\author{
Gerda de Villiers \\ Departement Ou-Testamentiese Wetenskap \\ Universiteit van Pretoria
}

\begin{abstract}
The dodekapropheton: Twelve minor prophets or a larger unit?

The Book of the Twelve or the twelve minor prophets received scholarly attention through the ages. Historical criticism pointed out that these prophets lived in different times, in different historical situations and articulated the "word of the Lord" for different circumstances. However, recent scholarship tends to read the corpus of the minor prophets as a structured whole. Such a reading raises a number of problems: the Twelve do not follow one another chronologically and the order of the Masoretic Text does not agree with that of the Septuagint, whilst Qumran follows yet another order. This article probes - albeit cursory - some of these questions from different perspectives. Eventually it appears that a continuous process of "Fortschreibug" shaped and reshaped prophetic messages to keep them alive for following generations. A unity is created by maintaining the tensions and differences amongst the Twelve, thereby reflecting the creative articulation and rearticulation of prophecy in the different times of the history of Judah and Israel.
\end{abstract}

\section{INLEIDING: KORT OORSIG}

Die twaalf kleinprofete, ook genoem die dodekapropheton verkondig God se genade en God se oordeel om die beurt. In die negentiende en twintigste eeue met die opkoms van die moderne kritiese Bybelwetenskappe, is die twaalf kleinprofete as individuele profetiese boeke gelees (Nogalski \& Sweeny 2000:vii). Volgens die diakroniese benadering is elke boek histories geïnterpreteer en geplaas binne die sosio-kulturele konteks waarop hulle betrekking het. Kronologies verloop die geskiedenis min of meer soos volg: Hosea en Amos, twee van die vroegste kleinprofete, se optredes word gedateer tydens die regering van Jerobeam II van Israel, ongeveer 790-150 vC (Boshoff 2000:107, 110). Gedurende hierdie tyd is Israel sowel as Juda 
erg afvallig, ontrou aan die Here, en sosiale wanpraktyke is aan die orde van die dag. Amos voorspel dat die Here se toorn gaan ontvlam, nie net teen die nasies nie, maar ook teen sy eie volk, terwyl Hosea Israel se afgodery en ontrou met aangrypende beeldspraak - die verhouding tussen 'n man en sy ontroue vrou - skilder.

Die tienstamme, Israel, verdwyn inderdaad van die toneel. Alhoewel Nahum (ongeveer $663 \mathrm{vC}$ ) (Boshoff 2000:127) 'n gewelddadige en brutale God uitbeeld, is dit veronderstel om hoop te gee: alhoewel God die Assiriërs gebruik het om sy volk te straf, gaan Hy eersdaags Nineve die onderdrukker, gelyk met die grond vee, en sy volk weer begenadig.

$\mathrm{Na}$ afloop van die ballingskap, begin hoop opvlam. Onder die Persiese regering word Juda toegelaat om na hul land terug te keer. Haggai en 'n ywerige jong Sagaria (Sag 1-8) - ongeveer 520-518 vC (vgl Spangenberg 2000:175-177) - moedig die volk ywerig aan om die huis van die Here te herbou. Die tyd om dit te doen, is nou, terwyl die Perse aan bewind is en terwyl hulle die geleentheid het.

Drome word egter verpletter toe die Grieke die wêreld begin inneem en die politieke en godsdienstige situasie in Juda verdonker. So voorspel Joël (2:28-3:21) (vgl Spangenberg 2000:182-183) dat die dag van die Here 'n oordeelsdag vir die nasies gaan wees wat met skrikwekkende kosmiese verskynsels gepaard gaan. Juda en Jerusalem gaan weer begenadig word, en die Here gaan weer op sy heilige berg woon.

Die Grieke het egter ook weer die groter wêreld oopgemaak. Eksklusiewe nasionalisme sou nie veel langer geduld word nie. 'n Groter bewuswording van God se universele liefde, ook vir ander, begin posvat. So kry die boek Jona gestalte, en vertel van 'n verloopte profeet met ' $n$ onvergenoegde houding. Hierdie gesindheid dra beslis nie God se goedkeuring weg nie, en Jona se voorbeeld moet liefs nie nagevolg word nie!

\section{PROBLEEMSTELLING}

Dit is duidelik dat die Twaalf nie kronologies gerangskik is nie. Byvoorbeeld, Joël en Jona, twee boeke wat reeds binne die eerste ses in die reeks voorkom, word laat gedateer. Maar dis veral die volgorde Jona-(Miga)-Nahum wat eksegete hoofbrekings verskaf het. As 'n mens bogenoemde datering aanvaar, en aanvaar dat Nineve reeds in $612 \mathrm{vC}$ deur Nebukadneser platgevee is (vgl Ego 2003:169), het die stad teen die tyd wat die boek Jona op skrif gestel is, lankal nie meer bestaan nie. Verder was Nineve wel die hoofstad van die Assiriese Ryk, maar nooit 'n onafhanklike stadstaat met 'n eie koning nie. Wat veral nie sin maak nie, is dat die groot stad Nineve volgens Jona deur God gespaar word, en in Nahum, twee boeke later word sy 
meedoënloos en brutaal uitgedelg. Aan die een kant is God genadig, barmhartig en bereid om sonde te vergewe. Aan die ander kant word God wreed en wraakgierig teenoor dieselfde stad uitgebeeld. Hoekom so?

Vroeëre geskrifte het die twee boeke op 'n manier probeer harmoniseer. Tobit, een van die vroeëre apokriewe boeke verwys na hierdie scenario. Hierdie boek is waarskynlik in die oostelike Joodse diaspora so ongeveer 200 vC op skrif gestel (Ego 2003:156). 'n Stokou Tobit roep sy seuns en sy kleinseuns, en sê vir sy seun Tobias: "My seun, ek is nou oud en dit is nie meer lank voor ek moet doodgaan nie. Vat jou kinders en gaan na Medië, my seun, want ek is vas oortuig dat dit wat die profeet Jona oor Nineve gesê het, gaan gebeur. Dit sal vernietig word ..." (Tobit 14:3-4). En in Tobit 14:15 word inderdaad vertel: "Voor hy dood is, het hy gehoor dat Nineve deur Nebukadneser en Ahasveros ingeneem en vernietig is en hy was bly dat dit gebeur het" (kyk ook Ego 2003:156; Jones 2000:73). Deur te fokus op die eerste gedeelte van die boek Jona, identifiseer Tobit Jona se profesie met die van Nahum: Nineve gaan vernietig word.

Volgens Josefus se interpretasie in Antiquitates 9.214 bid Jona tot die Here om sy sondes te vergewe (sien Ego 2003:157). Daarna verkondig hy dat die stad "Ninos" haar oorheersing oor Asië sal verloor en beklemtoon daarmee die boodskap van oordeel. In die lig van die aanname dat 'n ware profeet daaraan gekenmerk word dat sy woord uitkom, het hierdie vroeëre interpretasies waarskynlik geworstel met die vraag of Jona ' $n$ ware of 'n vals profeet is: 'n vals profeet verdien immers nie 'n plek in die kanon nie!

In die rabbynse tradisie speel die berou van Nineve 'n baie belangrike rol. Enersyds word die berou van die heidense Nineve voorgehou as 'n skitterende voorbeeld van wat ware berou eintlik moet wees. Die Gemara van die Babiloniese Talmud (b.Taan.16a - kyk Ego 2003:159) borduur voort op die berou van die mense van Nineve. Hulle het nie slegs gevas en gebid nie, hul gedrag het ook verander. Met hul dade het hulle duidelik bewys dat hulle vasberade was om 'n beter lewe te lei. As iemand 'n ander se eiendom wederregtelik toegeëien het, het hy sy bes gedoen om die saak reg te stel. Sommige het nie slegs die besittings teruggegee nie, maar so ver gegaan om hul eie paleise te vernietig sodat hulle 'n enkele baksteen aan die wettige eienaar kon teruggee.

Die Gemara van die Jerusalem Talmud (y.Taan 2.1, 65b - kyk Ego 2003:161) gee egter 'n ander perspektief. Volgens Rabbi Simeon ben Laqish en Rabbi Yohanan was die berou van die mense van Nineve blote skyn en bedrog. Wat hulle in hul hande gehad het, het hulle wel teruggegee, maar wat hulle in hul kiste en kaste weggesteek het, het hulle nie teruggegee nie. Hierdie tipe berou is oppervlakkig en skynheilig. 
Luidens die Midrash Pirke van rabbi Eliezar - 'n dokument uit die vroeë middeleeue - was dit inderdaad so dat Nineve op Jona se prediking tot bekering gekom het. Dit was egter van korte duur en gou het hulle weer na hul ou weë begin teruggly. Veertig jaar later - die tydperk wat tussen Jona en Nahum sou verloop - is God se oordeel voltrek (Ego 2003:160; Jones 2000:73; Reddit 2000:30; Schart 1998:27-28). Hierdie interpretasie maak van Jona 'n proleptiese profeet, eerder as 'n vals een!

Hedendaagse geleerdes respekteer die afstand en verskil tussen die twee boeke. Vir Jona sowel as Nahum gaan dit om die lot van Nineve. Nineve is nie noodwendig ' $n$ historiese werklikheid nie, maar ' $n$ simbool van ' $n$ tipiese vyand wat verdien om uitgedelg te word (Mason 1991:83; Coggins \& Re'emi 1985:12-13). Dit het veral te make met vals godsdiens en onmenslike onderdrukking en wreedheid. Nahum verkondig dat die Here die bevolking van Nineve gaan uitdelg as gevolg van hul selfvoldane hoogmoed en arwaan. Jona hou die moontlikheid voor dat selfs die verderflikste vyand gespaar kan word mits hulle berou betoon en hulle bekeer.

Jona en Nahum word ook op ander maniere met mekaar in verbinding gebring. In die Septuaginta word hulle nie deur Miga geskei nie, maar volg die een direk op die ander (die Septuaginta word by punt 6 in hierdie artikel bespreek). Verder is daar is ' $n$ paar interessante parallelle bewegings tussen die twee (Mason 1991:83). Jona 4:2 en Nahum 1:3 vertoon besonder sterk ooreenkomste met Eksodus 34:6 (kyk ook Schart 2000:41) - waar God beskryf word as barmhartig, lankmoedig en genadig, vol liefde en trou. Verder is hierdie twee boeke min of meer ewe lank. Laastens, maar beslis nie die minste nie, is Jona en Nahum die enigste twee boeke in die Ou Testament wat met ' $n$ vraag eindig. Die antwoord op hierdie vraag word oor ' $n$ teologiese boeg gegooi en die vreemde nasies word die "draer" om die soewereiniteit van die Here te beklemtoon: beide sy genade en oordeel word voltrek om uiteindelik geregtigheid en orde in hierdie wêreld te laat uitwerk.

\section{EEN BOEK, OF TWAALF?}

Die meeste vertalings - Afrikaans en Engels - plaas die twaalf kleinprofete wel as 'n reeks, maar as afsonderlike boeke van die Ou Testament. Daarenteen word hulle in die inhoudsopgawe van die Hebreeuse Bybel onder een hoofopskrif gegroepeer, naamlik Librum XII Prophetarum. Verder begin nie elke kleinprofeteboek noodwendig bo-aan 'n nuwe bladsy nie, maar die einde van die een loop doodnatuurlik oor na die begin van die volgende.

Hedendaagse eksegete, onder die invloed van die redaksie-kritiek gebruik die finale gestalte van die teks as basis om die ontstaan en ontwikkeling van 'n teks te ontsluit (die inleiding in Nogalski \& Sweeny 
2000:vii), en kom toenemend onder die indruk dat die dodekapropheton as een boek gelees moet word. Daar is heelwat bewyse (kyk Reddit 2003:1; Petersen 2000:4; Nogalski 1993:2-3):

- Die deutero-kanoniese boek, die Wysheid of Spreuke van Ben Sirag (2e eeu $\mathrm{vC}$ ) verwys in 'n gebed na die "beendere van die twaalf profete". Geleerdes maak die afleiding dat die Twaalf reeds in hierdie tyd as 'n enkele boek beskou is.

- Die Joodse historikus Flavius Josefus (1e eeu $\mathrm{nC}$ ) beskou die Twaalf as een van die twee en twintig boeke in die Bybel ( $A g A p$ 1.8).

- Esra 14:41 noem die Twaalf as een van die vier en twintig heilige boeke wat deur Esra oorgeskryf is.

- Die kerkvader Origenes (2e tot $3 e$ eeu $\mathrm{nC}$ ) tel ook die Twaalf as een boek in die Joodse Ou Testament.

- In die Babiloniese Talmud, Baba Batra 13b-15a is twee verwysings wat die eenheid van die Twaalf bevestig: (a) Noukeurige instruksies word gegee vir die oorskryf van Bybelboeke. Tussen kanoniese boeke moet vier blanko reëls gelaat word, maar die Twaalf word slegs deur drie oop reëls geskei; (b) Die orde waarin die Bybelboeke moet voorkom, word uitgestippel. Hier word kollektief na die Twaalf as een boek verwys.

- 'n letwat latere Hieronimus bevestig die eenheid eksplisiet: "unum librum esse duodecim prophetarum" (aanhaling uit Nogalski 2000:3).

- Intussen is antieke Hebreeuse en Griekse tekste ontdek waar die meeste van die kleinprofete - in sommige gevalle almal - op een rol opgeteken is (sien ook Tov 1990).

Natuurlik word hierdie bewyse deur ander geleerdes weerlê. Reddit (2003:3) verwys na die besware van Ehud ben Zvi (2003:283-292) wat onder andere aanvoer dat: (a) 'n Versameling impliseer nie noodwendig 'n samehangende geheel nie. 'n Boek soos Spreuke is 'n duidelike bewys van 'n tipe antieke bloemlesing wat deur antieke skrywers saamgestel is, sonder 'n koherente plan; (b) Latere gemeenskappe sedert Qumran tot die rabbi's, het die Twaalf as 'n bloemlesing beskou; (c) Die gebrek aan 'n vaste orde wat betref die eerste ses boeke (bespreking volg by punt 6 ), is verdere getuienis teen enige 
"korrekte" lesing; (d) Die opskrifte en aankondigings skei die profete van mekaar. Petersen (2000:3-10) volg 'n soortgelyke argument en beskou die versameling kleinprofete as 'n bloemlesing.

Hierdie argumente is egter besig om veld te verloor, en al hoe meer geleerdes verkies om die twaalf kleinprofete as 'n eenheid te lees.

\section{MOONTLIKE BEWYSE VIR 'N SAMEHANGENDE GEHEEL}

\section{1 'n Sistematiese groei van die profetekorps}

Nogalski (1993:5-7) en Schart (1998:6-8) sit kortliks navorsing rakende die sistematiese groei van 'n profetekorps uiteen. In 1921 het Budde aangevoer dat die Boek van die Twaalf gegroei het weens 'n sistematiese redaksie wat in die vierde eeu vC plaasgevind het (Nogalski 1993:5). Volgens hierdie teorie sou daar gepoog word om alle nie-goddelike materiaal in die Boek van die Twaalf te elimineer, insluitende narratiewe en eerste-persoonsvertellings. Boeke soos Jona, die styl van Haggai en Sagaria se naggesigte het hierdie hipotese egter laat misluk.

In 1935 verskyn Wolfe op die toneel (Schart 1998:6-7; Nogalski 1993:5-6). Hy doen baanbrekerswerk. Volgens sy hipotese was daar 'n historiese ontwikkeling wat in dertien redaksionele lae onderskei kan word. Hierdie lae kan gesien word in die groei van die korpus wat ontwikkel uit stadia bestaande uit eers twee, dan ses, dan nege en uiteindelik die twaalf boeke. Die vier stadia word soos volg aangetoon:

1. Hosea en Amos is die eerste twee kleinprofete;.

2. Bogenoemde word dan deel van die volgende ses: Amos, Hosea, Miga, Nahum Habakuk en Sefanja. Hierdie ses is die voor-eksiliese profete;

3. Vervolgens word Joël, Jona en Obadja ingevoeg en vorm die sogenaamde "boek van die nege";

4. Uiteindelik kom Haggai, Sagaria en Maleagi by, en die kleinprofetereeks word voltooi.

Wolfe se werk beïnvloed Dale Allen Schneiders om in 1979 ook met 'n hipotese rakende die "groei van 'n profetiese korpus" vorendag te kom (Schart 1998:8; Nogalski 1993:7). Hy stel 'n vier-fase groei van profetiese tradisies voor:

1. Hosea, Amos en Miga;

2. Nahum, Habakuk en Sefanja;

3. Joël, Obadja en Jona;

4. Haggai, Sagaria en Maleagi. 


\subsection{Die "dag van die Here"}

Die "groei van 'n profetiese korpus" is egter maar een kant van die munt. Sommige geleerdes wil 'n "tematiese" verbinding tussen die Twaalf kleinprofete insien. "Die dag van die Here" is byvoorbeeld 'n tema wat deurlopend en herhalend voorkom (Nogalski 2003:193). Tematies gesproke is die implikasie dat die betekenis van "die dag van die Here" wyer strek as die presiese woorde. Frases soos "op daardie dag" en "die dag" ensovoorts, is gelaai met betekenis. Dus, ten spyte daarvan dat die woorde jôm JHWH nie eksplisiet in die boeke Jona en Nahum voorkom nie, is die tema nietemin implisiet aanwesig.

\subsection{Stichworten}

Volgende "bindingsmiddel" is die sogenaamde Stichworten, oftewel catchwords. So vroeg soos 1851 bemerk Delitzch sekere woorde wat die twaalf kleinprofete bind - hetsy woordeliks of tematies. Bykans 'n eeu later tel Umberto Cassuto (1947) dieselfde fenomeen op en brei hierop uit (Nogalski 1993:6). Uiteindelik is dit Erich Bosshard (kyk Nogalski 1993:9; Schart 1998:9) wat die aandag vestig op parallelle tussen die twaalf kleinprofete en veral Jesaja. Byvoorbeeld, Hosea 1:1// Jesaja 1:1 - identiese verwysings na die vier Judese konings; Joel 2:1 // Jesaja 13:6 - die dag van die Here; Miga 4:14 en Jesaja 2:2-4 is identies.

Hierdie verbindinge tussen die kleinprofete is nie maar toevallig nie. Bogenoemde geleerdes is daarmee eens dat 'n redaksionele vormingsproses aan die werk was. Die Twaalf het doelbewus en beredeneerd motiewe van Jesaja oorgeneem en daarop voortgebou.

\section{DIE RESENTE DEBAT: DIAKRONIE OF SINKRONIE?}

\subsection{James Nogalski en Aaron Schart: Diakronie}

Nogalski (1993) is een van die mees resente navorsers oor die eenheid van die Twaalf en bou voort op die teorie van Stichworten: sy argument is dat die Twaalf Kleinprofete aan mekaar ge"ryg" word deur eerste en laaste woorde, met ander woorde, die laaste woorde van die vorige profeet, is die eerste woorde van die volgende. Sy navorsing sit hy in twee volumes uiteen: Literary precursors to the Book of the Twelve en Redactional processes in the Book of the Twelve, albei 1993. In die eerste werk verduidelik hy sy metodologie (Nogalski 1993:12-19). Hy teken eers beswaar aan teen navorsers wat te eenvoudig en eensydig met die finale gestalte van die teks werk. Vir Nogalski is so 'n benadering nie aanvaarbaar nie. Hy verkies om literêr en redaksiekrities te werk te gaan. Uiteraard kan sy twee volumes nie uitvoering binne die 
bestek van hierdie artikel bespreek word nie, derhalwe gaan ek sy redenasie baie kursories probeer uiteensit aan die hand van die lyne wat hy tussen Hosea en Joël trek (Nogalski 1993:58-73).

Binne die makrostruktuur van Hosea is dit baie duidelik dat Hosea 14:2-10 'n latere byvoeging is. Veral Hosea 14:8 besonder beduidend en die volgende Stichworten aan die einde van Hosea en die begin van Joël verdien aandag: beelde rondom koring, wingerd, wyn. Hierdie vers kyk enersyds terug na Hosea 2:8 en verder. Hier, in die vroeëre Hosea word Israel verwyt omdat sy die wyn en die graan, die landbouprodukte wat Jahwe haar gegee het, misbruik deur dit vir diens aan Baäl te wy. Hosea 14:8 spreek die hoop uit dat hierdie situasie reggestel gaan word, en die verhouding tussen die Here en die ontroue volk weer in ere herstel gaan word. Andersyds kyk Hosea 14:8 egter ook vorentoe na Joël, maar die verhouding met Joël is paradoksaal. 'n Geweldige spanning word geskep wanneer Hosea die prentjie van redding voorhou, maar Joël as 't ware 'n streep daardeur trek: niks bly oor van die wyn, die wingerde en die koring nie, alles is daarmee heen.

Joël eindig egter nie met totale uitwissing nie. Joël (4:18-21) maak weer beloftes van herstel, van wyn, hervestiging van die land, ensovoorts.

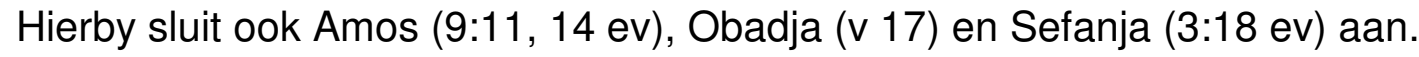
Vir Nogalski is Hosea 14:8'n doelbewuste redaksionele invoeging om parallel te skakel met ander soortgelyke verwysings in die Twaalf kleinprofete - en ook om die hoop wat aanvanklik in Joël verpletter word, deurentyd in stand te hou.

Dus, elke stichworter-verbinding moet individueel hanteer word om te sien of dit werklik die eenheid van die Twaalf belig. Wat vir een geval geld, is nie vanselfsprekend van toepassing op die volgende nie. Verskeie perspektiewe moet in gedagte gehou word (Nogalski 1993:15): die onmiddellike konteks van die woorde; die oorlewering van die individuele tekste; die funksie binne die Boek van die Twaalf; die teologiese/literêre verhouding met die res van die Ou Testament. Juis die kompleksiteit van die oorleweringsgeskiedenis van tekste kan moontlik veroorsaak dat Stichwortenverbindinge nie altyd voor-die-hand-liggend is nadat materiaal binne bestaande kontekste ingevoeg word nie.

Nogalski se teorie spring kritiek nie vry nie. Jones (1995:37-38) kritiseer sy aanname dat alle Stichworten die resultaat van redaksionele aktiwiteit is. Sy redaksie-kritiese metode is nie voldoende nie, en buitendien kan die woorde wat hy as Stichworten identifiseer, nie onweerlegbaar bewys word nie. Verder is sy volgende punt van kritiek dat Nogalski slegs die Masoretiese teks as vertrekpunt gebruik - die Septuaginta rangskik die kleinprofete anders maar dit kom nie in Nogalski se teorie ter sprake nie. 
Schart (1998), ietwat later op die toneel, sien 'n groei in die profetekorps met Amos as 'n soort literêr-historiese anker. Na aanleiding van die opskrifte wat sommige van die tekste dateer, identifiseer hy 'n eerste "versameling" wat bestaan uit Hosea, Amos, Miga en Sefanja. Hy noem dit die D-korpus aangesien dit moontlik tydens die deuteronomistiese geskiedskrywing vasgestel sou kon wees.

By hierdie oudste korpus word Nahum en Habakuk gevoeg. Schart (1998:242-244) sien 'n omramende "teofanie-himne" in Nahum 1:2-8 en Habakuk 3:3-15. Die geweld in die Nahum-teks skep spanning, maar wys ook vooruit na Habakuk. Die oordeel wat voltrek word, is die Gattungsbegriff en vorm die basis: Eers kom die Assiriërs aan die beurt, dan die Chaldeërs. Daarna word Haggai en Sagaria op grond van hulle datering bygevoeg, vervolgens Joël en Obadja wat deur die tema "die dag van die Here" gedomineer word. Die kleinprofetereeks word afgesluit met die ongedateerde Jona-satire en die eskatologiese Maleagi.

Schart (1998) bespreek elkeen van die kleinprofete indringend en toon ook onderliggende verbande aan. Benewens samestelling en struktuur, word die intensies van elke korpus ook uitgespel.

\subsection{Paul House: Sinkronie}

Teenoor Nogalski en Schart staan House (1990) se sinkroniese benadering. Hy (House 1990:67) is van mening dat die Twaalf kleinprofete deur literêre beginsels gestruktureer is, en dat historiese navorsing nie daarin slaag om hierdie beginsels bloot te lê nie. Hy identifiseer vervolgens wat hy 'n "comic plot" noem (skematies voorgestel op bladsy 124 in bogenoemde bron). Die basis van die plot is die verhouding tussen Jahwe en Israel: Israel as God se uitverkore volk, opstand/sonde, straf en vergifnis. Parallel hiermee loop ook God se verhouding met die nasies, en alhoewel dit nie die vernaamste fokuspunt is nie, onderstreep dit sy soewereiniteit. Sonde, straf, herstel is die vernaamste komponente van hierdie plot.

Die plot het 'n "U" vorm. Dit begin by Hosea en neig toenemend afwaarts. House (1990) skets drie bewegings: verbond en kosmiese sonde (Hosea tot Miga), verbond en kosmiese straf (Nahum tot Sefanja, met Nahum/Habakuk as die krisis-moment onderaan die "U"), hoop op herstel (Haggai tot Maleagi). Met "comic plot" bedoel House hoegenaamd nie iets wat snaaks is nie. Hy verduidelik dit soos volg (House 1990:162): "It rather means that the authors wrestle with the problems of sin and judgment, but do not find them to be the ultimate victors over the human race."

Tipies van 'n literêre werk, is daar ook karakters (House 1990:164219). Jahwe is die held en word op verskillende maniere gekarakteriseer - as 
eggenoot (Hosea), as heerser oor die kosmos (Joël/Obadja), familiehoof (Amos) ensovoorts. House (2000:129-145) het inderdaad 'n interessante karakter-studie van God in die Twaalf kleinprofete gemaak, byvoorbeeld: Hosea skets 'n God wat waarsku en liefhet (bl 129); Joël - God wat waarsku en belowe (bl 131); Amos - God wat sonde haat (bl 133); Obadja - God wat teen hoogmoed waarsku (bl 134); Jona - God wat heidene waarsku (bl 134); Miga - God wat teen sonde getuig (bl 136); Nahum - God wat Assirie verwoes (bl 137); Habakuk - God wat geloof in 'n krisis inspireer (bl 138); Sefanja - God wat straf ter wille van 'n oorblyfsel (bl 140); Haggai - God wat die tempel herstel (bl 141); Sagaria - God wat Jerusalem hernu (bl 142); Maleagi - God wat Israel liefhet en hernu (bl 143).

Naas Jahwe kom die karakters van profete aan die orde - as medekarakters skryf hulle saam aan die plot (House 1990:186). Hulle belangrikste rol is dié van Jahwe se boodskappers. Hierdie rol word nie altyd met woorde uitgeleef nie, maar ook simbolies - soos byvoorbeeld Hosea se huwelik met die ontroue Gomer. Israel en die nasies word ook gekarakteriseer - om die beurt word hulle óf begenadig óf delf die onderspit. House (1993:221-241) skenk laastens ook aandag aan die tegnieke van vertelling, eerste- derdepersoonsvertellers, geïmpliseerde gehoor ensovoorts om sy punt van 'n dramatiese "comic plot" in die Twaalf kleinprofete te bevestig.

House se benadering word egter skerp gekritiseer deur Jones (1995:31) weens sy openlike polemiek teen historiese kritiek. Ook Nogalski (1993:11) het probleme met House se metodologie. Sy kategorieë is so vaag dat dit op bykans enige van die profetiese geskrifte van toepassing gemaak kan word en hy bied nie genoegsame kriteria vir 'n argument van die kleinprofete as 'n literêre eenheid nie. Inderdaad, die bronnelys agter sy 1993boek, toon aan dat hy hoofsaaklik van die werke van literêre kritici, en nie teoloë nie, gebruik maak. Hierdie literatuurteorieë pas hy dan op die afsonderlike boeke en reeks van die kleinprofete toe. Dit maak wel interessante perspektiewe oop, maar lewer nie werklik 'n insiggewende bydrae tot die eenheidsdebat van die korpus nie.

\section{DRIE MOONTLIKE VOLGORDES}

Om sake verder te kompliseer, is daar ten minste drie manuskripte wat die twaalf kleinprofete in verskillende volgordes plaas (kyk Jones 1995:54 vir tabel). (Die kleinprofete wat van posisie verwissel, word hieronder beklemtoon.) Die Masoretiese teks (MT) volg die bekende orde: Hosea Joël Amos Obadja Jona Miga Nahum Habakuk Sefanja Haggai Sagaria Maleagi. Die Septuaginta (LXX) lyk anders: Hosea Amos Miga Joël Obadja Jona Nahum Habakuk Sefanja, Haggai Sagaria Maleagi. Laaste, maar nie die 
minste nie, is daar belangrike teksgetuienis van een van die Qumran-rolle, 4QXIla. Die eerste gedeelte ontbreek heeltemal, maar die laaste drie van die kleinprofete is: Sagaria Maleagi Jona. Dis dus veral Joël, Obadja en Jona wat van plek verwissel.

Geleerdes debatteer hewiglik oor watter volgorde die oorspronklike is. Steun die LXX op die volgorde van die MT, of is dit andersom? Is 4 QXIla dalk die oorspronklike aangesien dit Jona in die korrekte chronologiese volgorde laaste plaas?

Hierdie debat beland vir die afgelope aantal jare in 'n doodloopstraat. Sweeny (2000:49-64) bied 'n aantreklike selfs oortuigende alternatief. Hy stem saam dat die kleinprofete-reeks, nóg in die MT, nóg in die LXX chronologies begrond kan word. Nietemin, die orde is nie lukraak saamgeflans nie, maar doelbewus bedink en beredeneer (Sweeny 2000:55). Sy uitgangspunt is eers sinkronies: hy bekyk die twaalf kleinprofete in die MT en die LXX soos wat hulle in die onderskeie korpusse gerangskik is, en kom tot die gevolgtrekking dat elke volgorde 'n bepaalde hermeneutiek weerspieël. Nou kom die diakroniese vrae aan die orde, naamlik die situasie waarbinne die boeke ontvang is en uiteindelik tot ' $n$ geheel gegroei het.

Sweeny (2000:56) beklemtoon dat elke kleinprofeet outonoom kan staan - elke boek het 'n eie unieke inhoud, literêre struktuur, 'n sosiohistoriese agtergrond, en ' $n$ teologiese en ideologiese perspektief. Wanneer individuele boeke egter in verhouding met mekaar gelees word, verander die kommunikatiewe funksie en perspektief radikaal. ${ }^{1}$

Die MT en die LXX begin met Hosea en eindig met Maleagi. Hosea as inleiding en Maleagi as slot, is in beide korpusse funksioneel (Sweeny 2000:56-57). In poëtiese taal wat Israel as 'n ontroue vrou verbeeld, skets Hosea die verbrokkelde verhouding tussen die Here en sy volk, nogtans pleit hy dat die verhouding herstel. Maleagi se slotwoorde spreek ook die Here se weersin teen egbrekers uit, en doen ook 'n oproep om die verbond tussen die Here en Israel te herstel. Beide Maleagi en Hosea, gelees in verhouding tot mekaar, kry nuwe betekenis. Die belangrikste samebindende faktor tussen die Twaalf is die verhouding tussen die Here en sy volk: verbrokkeling, straf (deur die nasies), en herstel. Hierdie tema loop soos 'n goue draad deur die kleinprofete.

Die LXX stel vervolgens Amos, dan Miga aan die woord. Hierdie volgorde is nie kronologies nie, maar wel tematies (Sweeny 2000:26-27). Net soos Hosea, is Amos en Miga ook begaan oor Israel se verhouding met die

\footnotetext{
${ }^{1}$ Hierdie bespreking dek slegs die boeke Hosea tot Nahum, aangesien die verskille tussen die MT en LXX hierdie boeke raak. Daarna is die volgorde van die laaste ses boeke in beide korpusse dieselfde.
} 
Here, en sien uit na die uiteindelike herstel: nie net die herstel van die verhouding met Jahwe nie, maar ook die herstel van die volke Israel en Juda rondom die huis van Dawid en die tempel in Jerusalem.

'n Volgende fase word deur Joël ingelei met die kenmerkende "dag van die Here"-frase. Joël is veral vir hierdie doel geskik omdat duidelike historiese gegewens ontbreek, en omdat die vyand nie gespesifiseer word nie: dit kan op enige vyand van die volk van God dui. Obadja neem die tema op, en gee die vyand 'n naam: die Edomiete (Sweeny 2000:58). Die oordeel van "dag van Here" is op Edom gemik, omdat Edom onbetrokke teenoor die leed van die volk van Jakob gestaan het. Later eggo Maleagi hierdie sentimente van Obadja as hy getuig van die Here se liefde vir Jakob en sy weersin in Edom.

Jona - die boek van die verloopte profeet - weerspreek Obadja as 't ware, en gaan selfs verder. In hierdie boek word vertel van God se onbegrensde liefde wat nog wyer strek as net vir sy eie volk. Selfs die vyand, Assirië kan gered word, mits berou op die spyskaart is. Hierdie verhaal moet vir Israel inspireer: as Jahwe reageer op die berou en inkeer van die vyand, hoeveel te meer nie vir sy eie volk nie? Nahum wat in die LXX op Jona volg, onderstreep die tema van berou: geen berou, geen vergifnis. Volgens Nahum was Jahwe van die begin in beheer van sake. Hy het toegelaat dat Juda deur Assirië gestraf word; as gevolg van Assirië se aanmatigende houding straf $\mathrm{Hy}$ hulle; daar is egter ook die vooruitsig na 'n herstel en nuwe begin.

Vir die MT geld ander beginsels en word die Twaalf kleinprofete op 'n ander manier gerangskik. Hier is Hosea en Joël die twee inleidende boeke (Sweeny 2000:59). Hosea se roerende beskrywing van die gebroke verhouding tussen Jahwe en sy volk, en Joël se onheilspellende beskrywing van 'n bedreiging deur 'n onbekende vyand, open die toneel. Joël se kosmiese katastrofe op die "dag van die Here" radikaliseer Hosea se natuurlike rampe (Hos 4); hierdie tema word later weer in Sagaria opgeneem.

Hierna volg Amos (Sweeny 2000:59). Die scenario's wat Hosea en Joël geskets het, maak hy van toepassing op die Noordryk. Hul ondergang is gewis. Al Edom se besittings sal teruggegee word aan die volk van die Here (Amos 9:12) - en hierdie uitspraak is 'n voor-die-hand-liggende oorgang na Obadja. Die Here se wrewel en oordeel teenoor Edom in Obadja is fel. Obadja voorsien egter ook die herstel van Sion, 'n tema wat Maleagi oproep as vermaning om die wet van die Here te bly onthou.

Hierdie verskille dui moontlik op die verskillende wyses waarop die Boek van die Twaalf in verskillende historiese situasies ontvang en gelees is (Sweeny 2000:63-64). Die LXX onderskei verkillende fases: eers is die fokus op Israel en dan die nasies voordat Jerusalem se straf aan die orde kom. Hierdie orde is ook tipies van die LXX se weergawes van Jeremia en Esegiël. 
Dit is moontlik dat die LXX in die Aleksandrynse Judese diaspora ontstaan het, en die belange reflekteer van 'n Joodse gemeenskap wat daar 'n lewe moes uitwerk.

Die MT ontvou prosesmatig met die klem op Jerusalem van die begin en die einde waar die terugkeer na God in die vooruitsig gestel word. Die fokus is deurentyd op Jerusalem, selfs wanneer die straf van Israel en die nasies aangekondig word. Al hierdie ontwikkelinge het implikasies vir die suiwering van Jerusalem wat weer haar plek as die sentrum van Jahwe se wêreldsoewereiniteit gaan beklee. Hierdie lyn is kenmerkend van 'n inheemse Judese gemeenskap wat rondom Jerusalem sentreer en moontlik uit 'n Persiese of Hellenistiese periode dateer toe Jerusalem aan vreemde heerskappy onderworpe was.

\section{SLOT: ENKELE HERMENEUTIESE IMPLIKASIES}

Schart (2000:41-47) gee 'n aantal riglyne tot enkele hermeneutiese implikasies. Eerstens moet ' $n$ mens in berekening bring dat die oorspronklike woorde van die historiese profete radikaal herbewerk en oorbewerk is tydens die literêre oorleweringsproses (Schart 2000:46). Thiemeyer (2007:166) beklemtoon ook hierdie proses van Fortschreibung - die voortdurende ontwikkeling van die profetiese boeke deur lae en lae van interpretasies heen wat telkens byge "skryf" word met die doel om die profetiese boodskappe lewendig te hou vir die nageslag. Die woord van die Here moet suksesvol in verskillende historiese situasies "spreek". Dit was die doel van die oorspronklike profete, en dit is die doel wat die profetiese boeke nastreef.

Die literêre spatsels van die voor-eksiliese profete het vorm aangeneem toe die indruk geskep is dat die oorspronklike orakels vervul is (Schart 2000:46). Die volk het inderdaad in ballingskap gegaan. Sommige het egter die katastrofe oorleef. Hulle het daartoe bygedra dat die doemprofesieë in 'n profesieë van hoop omgeskakel kan word - dat God vrede en voorspoed in Israel binne 'n nuwe skepping sal herstel.

Die finale outeurs het gepoog om die profetekorps as 'n koherente geheel aan te bied. Elke nuwe orakel moet 'n verband kan toon met die literêre profetiese tradisie waarbinne dit staan. Dit beteken nie dat profetiese orakels onaangeraak bly nie, dit beteken wel dat elke nuwe orakel die drade van voorafgaande uitsprake optel en daarop uitbrei, omdat God Homself telkens nuut openbaar en telkens nuut beleef word (Schart 2000:46).

Die profetiese geskrifte is waarskynlik oorgedra as gedeeltes van 'n versameling (Schart 2000:47). Waarskynlik het die outeurs bestaande materiaal oorgeskryf en daarop uitgebrei. Hulle kon die oorspronklike gesegdes oorneem en vir die probleme van hul eie tyd van toepassing maak. 
Dit kon hulle slegs doen deur ' $n$ teologiese standpunt in te neem. Dit word die deurslaggewende faktor, dit bepaal wat binne die korpus geïntegreer word, en wat liefs geïgnoreer word. Uiteindelik gee die teologie 'n groter betekenis aan die geheel as die som van sy dele.

Die finale outeurs het egter nie gekies vir 'n vlak en vervelige samehang tussen die Twaalf nie. Hulle het al die spanninge en teenstrydighede behou. Daar is nie slegs een profeet wat die hele geskiedenis van Israel/Juda vanuit slegs een perspektief bekyk nie: daar is twaalf. In hierdie korpus van die Twaalf kleinprofete is twaalf verskillende profete van verskillende tye en elk met sy eie unieke perspektief aan die woord. Nogtans vorm hulle 'n eenheid, weliswaar ' $n$ komplekse eenheid, maar 'n eenheid wat fokus op die herstel van die teenwoordigheid van God in die geskiedenis (Schart 2000:47).

\section{Literatuurverwysings}

Ben Zvi, E 2003. The prophetic book: A key form of prophetic literature, in Sweeny, M A \& Ben Zvi, E (eds), The changing face of form criticism in the twenty first century, 267-292. Michigan, Ml: Eerdmans.

Boshoff, W 2000. The literature of the Northern Kingdom of Israel (922-721 BCE), in Boshoff, W, Scheffler, E \& Spangenberg I (eds), Ancient Israelite literature in context, 97-115. Pretoria: Protea Book House.

Boshoff, W 2000. The literature of the Southern Kingdom of Judah (922-586 BCE), in Boshoff, W, Scheffler, E \& Spangenberg I (eds), Ancient Israelite literature in Context, 116-141. Pretoria: Protea Book House.

Coggins, R J \& Reémi, S P 1985. Israel among the nations: Nahum, Obadiah, Esther. Michigan, MI: Eerdmans.

Ego, B 2003. The repentence of Nineveh in the story of Jonah and Nahum's prophecy in the city's destruction - A coherent reading of the Book of the Twelve as reflected in the Aggada, in Reddit, P L \& Schart A, Thematic threads in the Book of the Twelve, 134-155. Berlin: Walter de Gruyter.

House, P R 2000. The character of God in the Book of the Twelve, in Nogalski, J D \& Sweeny, M A, Reading and hearing the Book of the Twelve, 111-125. Atlanta, GA: Society of Biblical Literature.

House, P R 1990. The unity of the Twelve. Sheffield: Almond Press.

Jones, B A 2000. The Book of the Twelve as a witness to Ancient Biblical interpretation, in Nogalski, J D \& Sweeny, M A, 50-65. Reading and hearing the Book of the Twelve, Atlanta, GA: Society of Biblical Literature.

Jones, B A 1995. The formation of the Book of the Twelve: A study in text and canon. Atlanta, GA: Scholars Press.

Mason, R 1991. Micah, Nahum and Obadiah. Sheffield: JSOT.

Nogalski, J D \& Sweeny, M A 2000. Reading and hearing the Book of the Twelve. Atlanta, GA: Society of Biblical Literature. 
Nogalski, J D 2003. The day(s) of YHWH in the Book of the Twelve, in Reddit, P L \& Schart A, Thematic threads in the Book of the Twelve, 176-192. Berlin: Walter de Gruyter.

Nogalski, J 1993. Literary precursors to the Book of the Twelve. Berlin: Walter de Gruyter.

Nogalski, J 1993. Redactional processes in the Book of the Twelve. Berlin: Walter de Gruyter.

Reddit, $P L$ 2003. The formation of the Book of the Twelve: A review of research, in Reddit, P L \& Schart A, Thematic threads in the Book of the Twelve, 1-26. Berlin: Walter de Gruyter.

Reddit, P L 2000. The production and reading of the Book of the Twelve, in Nogalski, J D \& Sweeny, M A, Reading and hearing the Book of the Twelve, 4-11. Atlanta, GA: SBL.

Rendtorff, R 2000. How to read the Book of the Twelve as a theological unity, in Nogalski, J D \& Sweeny, M A, reading and hearing the Book of the Twelve, 66-75. Atlanta, GA: SBL.

Petersen, D L 2000. A Book of the Twelve?, in Nogalski, J D \& Sweeny, M A, Reading and hearing the Book of the Twelve, 4-11. Atlanta, GA: SBL.

Schart, A \& Reddit PL 2003. Introduction in Reddit, P L \& Schart, A, Thematic threads in the Book of the Twelve, ix-xvi. Berlin: Walter de Gruyter.

Schart, A 2000. Reconstructing the redaction history of the twelve prophets: Problems and models, in Nogalski, J D \& Sweeny, M A, Reading and hearing the Book of the Twelve, 12-34. Atlanta, GA: SBL.

Schart, A 1998. Die Entstehhung des Zwölfprophetensbuchs: Neuarbeitungen von Amos im Rahmen schriftenübergreifender Redaktionsprozesse. Berlin: Walter de Gruyter.

Spangenberg, I 2000. The literature of the Persian Period (539-333 BCE), in Boshoff, W, Scheffler, E \& Spangenberg I (eds), Ancient Israelite literature in context, 168-198. Pretoria: Protea Book House.

Sweeny, M A 2000. Sequence and interpretation in the Book of the Twelve, in Nogalski, J D \& Sweeny, M A, Reading and hearing the Book of the Twelve, 35-49. Atlanta, GA: SBL.

Thiemeyer, L-S 2007. Recent currents in research on the prophetic literature. $E T$ 119(4), 161-169.

Tov, E 1990. The Greek minor prophets scroll from Naḥal Hever: 8 Hev XII gr. Oxford: Clarendon.

Aanhaling uit Tobit in Van der Watt, J \& Tolmie, F 2005. Apokriewe: Ou en Nuwe Testament. Vereeniging: Christelike Uitgewersmaatskappy. 